\title{
Analysis of the Influence of the Work Environment on Employee Performance at the Institute of Domestic Administration, South Sulawesi Campus
}

\author{
Ikhsan Ilmuddin ${ }^{1}$, Andi Mamu ${ }^{2}$ \\ ${ }^{1}$ Master of Management Postgraduate Program, Faculty of Economics, Patria Artha \\ University, Indonesia \\ ${ }^{2}$ Institute of Domestic Administration, Indonesia \\ Received: November 4, 2021 \\ Revised: November 29, 2021 \\ Accepted: December 8, 2021
}

\begin{abstract}
The purpose of this study was to analyze the effect of the work environment on employee performance at the Institute of Domestic Administration, South Sulawesi Campus. This study uses quantitative descriptive. This research was conducted at the Institute of Domestic Administration, South Sulawesi Campus. The results of this study indicate a significant influence between the work environment (X1) on employee performance (Y) at the Institute of Domestic Administration, South Sulawesi Campus because t count $=5,800>t$ table, and the value of $\mathrm{t}$ sig. $=0.000<0.05$. The work environment has a positive and significant effect on employee performance at the Institute of Domestic Administration, South Sulawesi Campus.
\end{abstract}

Keywords: Work Environment, Employee Performance, Institute of Domestic Government

\section{Introduction}

Human resource management (HRM) is part of organizational management that focuses on the elements of human resources (Hamid et al., 2020). The task of HRM is to manage the human element well in order to obtain workers who are able to carry out their work well. In organizations, people are one of the most important elements in an organization. Without the role of humans even though the various needed factors are available, the organization will not run. Humans are the movers and determinants of the running of an organization. Therefore, the organization should provide positive direction to its employees in order to achieve organizational goals.

One of the factors that influence employee performance improvement is to pay attention to the work environment. The work environment is everything that is around the workers that can affect them in carrying out the tasks assigned, such as cleaning, music and so on (Harapan \& Kesumawati, 2021). The physical work environment in an agency is a working condition to provide a comfortable working atmosphere and situation for employees in achieving the goals desired by the agency concerned. A bad work environment has the potential to cause employees to fall ill easily, get stressed easily, find it difficult to concentrate which can result in decreased performance (Suryawan et al., 2020). Just imagine, if the work space is uncomfortable, hot, air circulation is inadequate, the work space is too crowded, the work environment is not clean, noisy, of course it will have a big impact on employee work comfort. In achieving workplace comfort, among others, it can be done by maintaining physical infrastructure such as cleanliness that is always maintained, adequate light lighting, air ventilation, sound music and a comfortable office layout. In addition to the physical work environment, the non-physical work environment also affects employee performance. If employees are not able to create a good work environment among other employees, it will interfere with employee performance. The work environment can create a binding working relationship between the people in the environment. 
In addition to the work environment, effective communication within the agency is also needed to produce the desired performance of an agency. Communication is a basic human activity. By communicating, humans can relate to each other both in everyday life at home, at work, and in the community (Fuchs, 2021). The importance of communication for humans cannot be denied, as well as for an agency.

Communication has an important role in an agency (Deverell et al., 2015). With good communication, every activity in an agency can run smoothly and vice versa, lack or absence of communication will be bad for the agency. Communication within the organization serves to provide information to all members of the organization. Communication also has a regulatory function, namely the leader can convey agency rules that must be enforced (Hallenbeck, 2012). In addition, communication also has a persuasive function, namely the leadership can encourage employees to be able to do their work more voluntarily, as well as an integrative function that can create an integrated agency environment. With the creation of a good work environment and communication, the performance of employees will also increase so that agency goals can be achieved. Employee performance is an action taken by employees in carrying out the work that is their responsibility (Handoko, 2014).

Every agency always expects its employees to work well, because having employees who have good performance will make an optimal contribution to the agency where they work. According to Siagian \& Khair (2014) that employee performance is influenced by several factors, namely: salary, work environment, organizational culture, leadership and work motivation, work discipline, job satisfaction, communication and other factors. The level of success of an agency can be seen from the performance of the agency in managing its resources. Agencies with good performance, have effectiveness in handling their human resources, determine targets to be achieved both individually and in their organization (Armstrong, 2010). The benefits of performance appraisal are performance improvement, compensation performance adjustments, placement decisions, training and development needs, career planning and development, staffing process definition, inaccurate information, job design errors, equal job opportunities, external challenges, HR feedback (Mangkuprawira, 2014).

The condition of the work environment at the Institute of Domestic Administration, South Sulawesi Campus when viewed from the work environment that is in the room. The work environment includes a place to work, facilities and work aids, cleanliness, lighting, tranquility. In addition to the physical work environment, the non-physical work environment must also be considered. This non-physical work environment can be a relationship between employees. Problems that occur in the work environment such as a clean workspace, good lighting, available work facilities, but sometimes during service hours students crowd in the administration room so that it becomes a bit noisy, causing disturbance to other employees. In addition, the relationship between employees is sometimes at odds because of different opinions.

In addition to paying attention to the work environment, communication within the agency must be well established. Two-way communication that occurs within the agency goes well, but there are times when the intent is not clear from the information submitted, such as the delivery of assignments or other information related to work. In addition, communication with external parties must also be considered, where the Institute of Domestic Administration of the South Sulawesi Campus is engaged in the field of educational services so that it requires every employee to establish good relations with stakeholders such as lecturers, students, parents of students, the Ministry of Home Affairs and the provincial government and district/city. The purpose of this study was to analyze the effect of the work environment on employee performance at the Institute of Domestic Administration, South Sulawesi Campus. 


\section{Methods}

This study uses quantitative descriptive. This research was conducted at the Institute of Domestic Administration, South Sulawesi Campus. The instrument in this study was used to measure the variables of the work environment, communication and performance in the form of questionnaires and documentation. The measurement used in this study is a measurement with a Likert scale. There are several tests in this study, including: Validity Test, Classical Assumption Test, Reliability Test, Hypothesis Testing.

\section{Results and Discussion}

\section{Descriptive Analysis of Research Variables}

\section{Work Environment Variables}

The work environment is everything that is around the employee that affects him in carrying out his duties at the Institute of Domestic Administration, South Sulawesi Campus. The description of respondents' answers to the work environment variable can be seen in the recapitulation of the frequency of respondents' answers to the work environment variable, which can be seen in table 1 .

Table 1. Lighting in IPDN Office

\begin{tabular}{|c|c|c|}
\hline Description & Frequency & Percentage \\
\hline Strongly Agree & 13 & 30,2 \\
Agree & 27 & 62,8 \\
Somehow Agree & 3 & 7,0 \\
Disagree & - & - \\
Strongly Disagree & - & - \\
\hline Total & 43 & 100 \\
\hline
\end{tabular}

Source: Research Data Results, 2020

Table 1 shows that from 43 respondents there are 13 respondents (30.2\%) who strongly agree, then 27 respondents $(62.8 \%)$ agree, then 3 respondents $(7.0 \%)$ who disagree and no respondents agree. disagree and strongly disagree. This means that most of the respondents stated that the lighting in the IPDN Office supports a comfortable work situation.

The frequency of respondents' answers to air circulation in the IPDN office can be presented in the following table:

Table 2. Air Circulation in IPDN Office

\begin{tabular}{|c|c|c|}
\hline Description & Frequency & Percentage \\
\hline Strongly Agree & 11 & 25,6 \\
Agree & 29 & 67,4 \\
Somehow Agree & 3 & 7,0 \\
Disagree & - & - \\
Strongly Disagree & - & - \\
\hline Total & 43 & 100 \\
\hline
\end{tabular}

Source: Research Data Results, 2020

Table 2 shows that from 43 respondents there are 11 respondents (25.\%) who strongly agree, then 29 respondents $(67.4 \%)$ agree, then 3 respondents $(7.0 \%)$ who say they do not agree and there are no respondents who say disagree and strongly disagree. This means that most of the respondents stated that the air circulation in the IPDN Office supports the health of the employees, although there are still 3 respondents who stated that they did not agree, this was

Copyright $@$ 2021, Journal of Asian Multicultural Research for Economy and Management Study, 
more because there were rooms that did not have windows. The frequency of respondents' answers to the environmental atmosphere at the IPDN Office can be presented in the following table:

Table 3. Environment atmosphere in IPDN Office

\begin{tabular}{|c|c|c|}
\hline Description & Frequency & Percentage \\
\hline Strongly Agree & 16 & 37,2 \\
Agree & 26 & 60,5 \\
Somehow Agree & 1 & 2,3 \\
Disagree & - & - \\
Strongly Disagree & - & - \\
\hline Total & 43 & 100 \\
\hline
\end{tabular}

Source: Research Data Results, 2020

Table 3 shows that from 43 respondents there are 16 respondents (37.2\%) who strongly agree, then 26 respondents $(60.5 \%)$ agree, then 1 respondent $(2.3 \%)$ who disagrees and no respondent agrees. disagree and strongly disagree. This means that most of the respondents stated that the atmosphere of the IPDN Office environment was calm, not noisy. The frequency of respondents' answers to odors around the IPDN office can be presented in the following table:

Table 4. Annoying odours around IPDN offices

\begin{tabular}{|c|c|c|}
\hline Description & Frequency & Percentage \\
\hline Strongly Agree & 20 & 46,5 \\
Agree & 23 & 53,5 \\
Somehow Agree & - & - \\
Disagree & - & - \\
Strongly Disagree & - & - \\
\hline Total & 43 & 100 \\
\hline
\end{tabular}

Source: Research Data Results, 2020

Table 4 shows that from 43 respondents there were 20 respondents $(46.5 \%)$ who strongly agreed, then 23 respondents (53.5\%) agreed and no respondents stated that they did not agree, disagree and strongly disagree. This means that most of the respondents stated that there is no smell around the IPDN office that disturbs the employees' concentration at work. The frequency of respondents' answers to job security guarantees can be presented in the following table:

Table 5. Work Security Guarantee at IPDN Office

\begin{tabular}{|c|c|c|}
\hline Description & Frequency & Percentage \\
\hline Strongly Agree & 12 & 27,9 \\
Agree & 28 & 65,1 \\
Somehow Agree & 3 & 7 \\
Disagree & - & - \\
Strongly Disagree & - & - \\
\hline Total & 43 & 100 \\
\hline
\end{tabular}

Source: Research Data Results, 2020

Table 5 shows that from 43 respondents there are 12 respondents (27.9\%) who strongly agree, then 28 respondents $(65.1 \%)$ agree, then 3 respondents $(7 \%)$ say they do not agree and there are no respondents who disagree and strongly disagree. This means that most of the respondents

Copyright @ 2021, Journal of Asian Multicultural Research for Economy and Management Study, 
stated that there is a work security guarantee that ensures the safety of the employees, although there are still 3 respondents who stated that they did not agree, this was more because the office access was very far away. The frequency of respondents' answers to the relationship between subordinates and leaders can be presented in the following table:

Table 6. The Relationship Between Subordinates and Leaders

\begin{tabular}{|c|c|c|}
\hline Description & Frequency & Percentage \\
\hline Strongly Agree & 13 & 30,2 \\
Agree & 28 & 65,1 \\
Somehow Agree & 2 & 4,7 \\
Disagree & - & - \\
Strongly Disagree & - & - \\
\hline Total & 43 & 100 \\
\hline
\end{tabular}

Source: Research Data Results, 2020

Table 6 shows that from 43 respondents there are 13 respondents (30.2\%) who strongly agree, then 28 respondents $(65.1 \%)$ agree, then 2 respondents $(4.7 \%)$ say they do not agree and there are no respondents who do not. agree and strongly disagree. This means that most of the respondents stated that there is a good relationship between subordinates and leaders. The frequency of respondents' answers to the relationship between co-workers can be presented in the following table:

Table 7. Relationships Between Coworkers

\begin{tabular}{|c|c|c|}
\hline Description & Frequency & Percentage \\
\hline Strongly Agree & 18 & 41,9 \\
Agree & 24 & 55,8 \\
Somehow Agree & 1 & 2,3 \\
Disagree & - & - \\
Strongly Disagree & - & - \\
\hline Total & 43 & 100 \\
\hline
\end{tabular}

Source: Research Data Results, 2020

Table 7 shows that from 43 respondents there were 18 respondents (41.9\%) stated strongly agree, then 24 respondents $(55.8 \%)$ agreed, then 1 respondent $(2.3 \%)$ stated less agree and no respondent disagreed. agree and strongly disagree. This means that most of the respondents stated that there is a good relationship between colleagues.

\section{Employee Performance Variables}

Employee performance is the result of work in quality and quantity achieved by an employee in carrying out his duties in accordance with the responsibilities given to him. The description of the leader's assessment of the employee performance variable can be seen in the recapitulation of the frequency of the leader's assessment of the employee performance variable, which can be seen in table 4.17.

Table 8. Quantity of Employee Work in IPDN Office

\begin{tabular}{|c|c|c|}
\hline Description & Frequency & Percentage \\
\hline Strongly Agree & 11 & 25,6 \\
Agree & 26 & 60,5 \\
Somehow Agree & 6 & 14 \\
Disagree & - & - \\
\hline
\end{tabular}




\begin{tabular}{|c|c|c|}
\hline Strongly Disagree & - & - \\
\hline Total & 43 & 100 \\
\hline
\end{tabular}

Source: Research Data Results, 2020

Table 8 shows that from 43 employees there are 11 employees $(25.6 \%)$ who were given the answer strongly agree, then 26 employees $(60.5 \%)$ were given the answer agree and then 6 employees (14\%) were given the answer disagree and no employees who were given the answer agree and strongly disagree. This means that most employees have the ability to work according to the set time target, although there are still some employees who have not been able to work according to the target time because sometimes at certain times there are many activities that have the same schedule. The frequency of respondents' answers to the quality of employees in working at the IPDN office can be presented in the following table:

Table 9. Quality of Employee Work in IPDN Office

\begin{tabular}{|c|c|c|}
\hline Description & Frequency & Percentage \\
\hline Strongly Agree & 14 & 32,6 \\
Agree & 27 & 62,8 \\
Somehow Agree & 1 & 2,3 \\
Disagree & 1 & 2,3 \\
Strongly Disagree & - & - \\
\hline Total & 43 & 100 \\
\hline
\end{tabular}

Source: Research Data Results, 2020

Table 9 shows that from 43 employees there are 14 employees $(32.6 \%)$ who were given a strongly agree answer, then 27 employees $(62.8 \%)$ were given an agree answer and then 1 employee $(2.3 \%)$ was given an answer. disagree and disagree and no employee was given a strongly disagree answer. This means that most employees have the ability to complete work accurately and thoroughly, although there are still some employees who have not been able to complete their work accurately and thoroughly, especially with regard to writing certain reports. The frequency of respondents' answers to the reliability of employees in working at the IPDN office can be presented in the following table:

Table 10. Reliability of Employee Work in IPDN Office

\begin{tabular}{|c|c|c|}
\hline Description & Frequency & Percentage \\
\hline Strongly Agree & 17 & 39,5 \\
Agree & 26 & 60,5 \\
Somehow Agree & - & - \\
Disagree & - & - \\
Strongly Disagree & - & - \\
\hline Total & 43 & 100 \\
\hline
\end{tabular}

Source: Research Data Results, 2020

Table 10 shows that from 43 employees there are 17 employees (39.5\%) who were given the answer strongly agree, then 26 employees $(60.5 \%)$ were given the answer agree and then no employee was given the answer disagree, disagree and strongly disagree. agree. This means that most employees have the ability to complete work accurately without any fatal errors. The frequency of respondents' answers to the presence of employees at work at the IPDN Office can be presented in the following table: 
Table 11. Accuracy of Employees Entering the IPDN Office

\begin{tabular}{|c|c|c|}
\hline Description & Frequency & Percentage \\
\hline Strongly Agree & 18 & 41,9 \\
Agree & 25 & 58,1 \\
Somehow Agree & - & - \\
Disagree & - & - \\
Strongly Disagree & - & - \\
\hline Total & 43 & 100 \\
\hline
\end{tabular}

Source: Research Data Results, 2020

Table 11 shows that from 43 employees there are 18 employees (41.9\%) who were given the answer strongly agree, then 25 employees $(58.1 \%)$ were given the answer agree and then no employee was given the answer disagree, disagree and strongly disagree. agree. This means that most employees arrive at the office on time. The frequency of respondents' answers to the presence of employees at work at the IPDN Office can be presented in the following table:

Table 12. Accuracy of Returning Employees at IPDN Office

\begin{tabular}{|c|c|c|}
\hline Description & Frequency & Percentage \\
\hline Strongly Agree & 16 & 37,2 \\
Agree & 26 & 60,5 \\
Somehow Agree & 1 & 2,3 \\
Disagree & - & - \\
Strongly Disagree & - & - \\
\hline Total & 43 & 100 \\
\hline
\end{tabular}

Source: Research Data Results, 2020

Table 12 shows that from 43 employees there are 16 employees (37.2\%) who were given the answer strongly agree, then 26 employees $(60.5 \%)$ were given the answer agree and then 1 employee $(2.3 \%)$ was given the answer disagree and no employee was given an answer agree and strongly disagree. This means that most employees go home on time according to office hours. The frequency of respondents' answers to the cooperation ability of employees at the IPDN Office can be presented in the following table:

Table 13. Ability to Cooperate employees in IPDN Office

\begin{tabular}{|c|c|c|}
\hline Description & Frequency & Percentage \\
\hline Strongly Agree & 11 & 25,6 \\
Agree & 30 & 69,8 \\
Somehow Agree & 2 & 4,7 \\
Disagree & - & - \\
Strongly Disagree & - & - \\
\hline Total & 43 & 100 \\
\hline
\end{tabular}

Source: Research Data Results, 2020

Table 13 shows that from 43 employees there are 11 employees (25.6\%) who were given the answer strongly agree, then 30 employees $(69.8 \%)$ were given the answer agree and then 2 employees (4.7\%) were given the answer disagree and no employee was given an answer agree and strongly disagree. This means that most employees are able to cooperate with other employees in completing their work and duties, although there are still employees who are difficult to work with. 


\section{Regression Coefficient}

The regression coefficient values of the estimation results using the Ordinary least square method are shown in table 14

Table 14. Regression Coefesien Values and Their Test Results

Coefficients $^{\mathrm{a}}$

\begin{tabular}{|c|c|c|c|c|c|c|}
\hline \multirow{2}{*}{\multicolumn{2}{|c|}{ Model }} & \multicolumn{2}{|c|}{$\begin{array}{c}\text { Unstandardized } \\
\text { Coefficients }\end{array}$} & \multirow{2}{*}{$\begin{array}{c}\text { Standardized } \\
\text { Coefficients } \\
\text { Beta }\end{array}$} & \multirow[t]{2}{*}{$\mathrm{t}$} & \multirow[t]{2}{*}{ Sig. } \\
\hline & & B & Std. Error & & & \\
\hline \multirow[t]{3}{*}{1} & (Constant) & ,364 & , 409 & &, 890 & ,379 \\
\hline & $\mathrm{X} 1$ &, 592 &, 102 & ,548 & 5,800 &, 000 \\
\hline & $\mathrm{X} 2$ & 308 & .065 & 445 & 4,711 & 000 \\
\hline
\end{tabular}

Source: Research Data Results, 2020

Table 4.26. can be explained as follows: Column (B) shows the values of the regression coefficients for the constant and each independent variable (X1 and X2), column (Std. Error) shows the standard error value for the regression coefficient parameter, column (Beta) shows the magnitude standardized regression coefficients or showing path coefficients, column (t) shows the t-count value for each regression coefficient parameter, and column (Sig.) indicates the magnitude of the probability of an error occurring (this value will be compared with ).

The results of the estimation of the regression coefficient above are obtained by the following regression equation:

$$
Y=0,364+0,592 X_{1}+0,308 X_{2}
$$

Based on the equation above, it turns out that the coefficients of $\mathrm{X} 1$ and $\mathrm{X} 2$ are positive, which means that if there is a change in the $X$ variables, it will cause a unidirectional change in the $Y$ variable, or if $\mathrm{X} 1$ and $\mathrm{X} 2$ are increased, the $\mathrm{Y}$ variable will also increase. Also, if the $\mathrm{X} 1$ and $\mathrm{X} 2$ variables are lowered, the $\mathrm{Y}$ variable will also decrease. From the equation of the regression model can be analyzed as follows:

Constant $=0.364$ means that the performance of employees at the Institute of Domestic Administration, South Sulawesi Campus is 0.364 if the variables of the work environment (X1) and communication $(\mathrm{X} 2)=0$.

The work environment variable (X1) has a positive effect of 0.592 on the employee performance variable (Y) at the Institute of Domestic Administration, South Sulawesi Campus, if other variables are constant.

\section{Hypothesis Testing}

Testing the first and second hypotheses in the study, it is suspected that the work environment affects employee performance at the Institute of Domestic Administration, South Sulawesi Campus and communication affects employee performance at the Institute of Domestic Administration, South Sulawesi Campus, using the t test. In this test, it is done by comparing the calculated $t$ value of each variable with the $t$ table value at the error degree $(\alpha)$ of 0.05 or $5 \%$. If the value of $t$ count $>t$ table, it means that the variable $X$ individually has a significant influence on the value of $Y$.

Based on the data about the t-count analysis in table 4.27 and which is compared with the $\mathrm{t}$ table at $/ 2=0.025 \mathrm{db}(\mathrm{n}-2)=(43-2)=2.0195$ from the results of SPSS data processing, it can be explained as follows: 
There is a significant effect between the work environment (X1) on employee performance (Y) at the Institute of Domestic Administration, South Sulawesi Campus because t count $=5,800$ $>\mathrm{t}$ table, and the value of $\mathrm{t}$ sig. $=0.000<0.05$

\section{Impact of the Work Environment on Employee Performance}

The work environment is everything that is around employees at work, both physical and nonphysical that can affect employees at work. If the work environment is conducive then employees can be safe, comfortable and if the work environment is not supportive then employees cannot be safe and comfortable. The work environment consists of the physical and non-physical environment attached to employees so that they cannot be separated to get good employee performance.

Based on the results of the regression analysis, it shows that the work environment has a positive effect, namely 0.592 , which means that every increase in one unit of the work environment variable will result in an increase of 0.592 in the performance of employees at the Institute of Domestic Administration, South Sulawesi Campus.

Based on the results of the $t$ test, it shows that there is a significant influence between the work environment on employee performance at the Institute of Domestic Administration, South Sulawesi Campus. The findings above are in line with Angel's research (Ariani et al., 2020) that the work environment in organizations is an important factor for employee performance, especially in public organizations so that the leadership must pay attention to this by providing a conducive work environment to work because the work environment Poor performance has the potential to cause employees to fall ill easily, get stressed easily, find it difficult to concentrate which can result in decreased performance.

\section{Conclusion}

The results of multiple regression analysis show that the work environment has a positive and significant effect on employee performance at the Institute of Domestic Administration, South Sulawesi Campus. Where every increase in the work environment variable will result in an increase in employee performance.

\section{References}

Ariani, D. R., Ratnasari, S. L., \& Tanjung, R. (2020). Pengaruh motivasi, lingkungan kerja, dan pengalaman kerja terhadap kinerja karyawan PT. Super Box Industries. Jurnal Dimensi, 9(1), 74-86.

Armstrong, M. (2010). Armstrong's essential human resource management practice: A guide to people management. Koganpage, London Philadelphia New Delhi.

Deverell, E., Olsson, E. K., Wagnsson, C., Hellman, M., \& Johnsson, M. (2015). Understanding public agency communication: The case of the Swedish armed forces. Journal of public affairs, 15(4), 387-396.

Fuchs, C. (2021). Everyday life and everyday communication in coronavirus capitalism. In Communicating COVID-19. Emerald Publishing Limited.

Hallenbeck, S. (2012). User agency, technical communication, and the 19th-century woman bicyclist. Technical Communication Quarterly, 21(4), 290-306.

Hamid, Z., Muzamil, M., \& Shah, S. A. (2020). Strategic human resource management. In Handbook of research on positive organizational behavior for improved workplace performance (pp. 260-275). IGI Global. 
Handoko, W. (2014). Kebijakan Hukum Pertanahan; Sebuah Refleksi Keadilan Hukum Progresif. Thafa Media: Yogyakarta.

Harapan, E., \& Kesumawati, N. (2021). The Influence of Academic Supervision of School Heads and Work Environment on Teacher Job Satisfaction. Jurnal Pendidikan Tambusai, 5(1), 2536-2541.

Mangkuprawira, T. S. (2014). Pengertian Pelatihan. Gramedia, Jakarta Pusat.

Siagian, T. S., \& Khair, H. (2018). Pengaruh Gaya Kepemimpinan Dan Lingkungan Kerja Terhadap Kinerja Karyawan Dengan Kepuasan Kerja Sebagai Variabel Intervening. Maneggio: Jurnal Ilmiah Magister Manajemen, 1(1), 59-70.

Suryawan, I. W. P., Suardhika, I. N., \& Suarjana, I. W. (2020). Pengaruh Lingkungan Kerja Dan Stres Kerja Terhadap Kinerja Karyawan Pada Hotel Peninsula Bay Resort, Tanjung Benoa. VALUES, 1(3), 106-117. 